\title{
“现代人类行为是如何形成的?”: 心理学的视角
}

\author{
白学军 ${ }^{*}$, 李卉 \\ 天津师范大学心理与行为研究院, 天津 300074 \\ *联系人, E-mail: bxuejun@126.com
}

2016-03-07 收稿, 2016-05-04 修回, 2016-05-04 接受, 2016-08-16 网络版发表

摘要 “现代人类行为是如何形成的?”是很多研究者一直试图回答的一个重要的科学问题. 进化心理学是近年 来一股新的心理学思潮. 其基本观点是: 人的心理包括成千上万个进化的模块，这些模块是心理适应环境的结果。 本文从进化论的角度出发, 运用进化生物学的资料和方法来探讨人类心灵的起源. 我们认为, 现代人的行为是缓 慢进化，适应环境的产物，同时人的行为还受到文化的影响.

关键词人类行为, 智人, 进化论, 心理学, 文化

2005年, Science杂志于创刊125周年之际发表了 一个特刊文章, 列出了 125 个最具挑战性的科学问题 (http://www.sciencemag.org/content/309/5731/78.2.full). 其中的一个问题为: “现代人类行为是如何形成的 (What gave rise to modern human behavior)?”对这个 问题的描述: 智人获得抽象思维、语言和艺术是缓慢 发生的? 还是以发生于 4 万年前欧洲的文化“大爆炸” 方式获得的? 也许来自非洲的关于我们人类如何起 源的数据能够回答这个困扰我们很久的问题(Did Homo sapiens acquire abstract thought, language, and art gradually or in a cultural "big bang", which in Europe occurred about 40000 years ago? Data from Africa, where our species arose, may hold the key to the answer).

智人的出现是人类进化历史上重要的里程碑, 现代人类都属于智人或智人的后代. 很多学者都认 为, 人类起源于现在的非洲东部 ${ }^{[1]}$, 然后慢慢开始迁 移和扩散到世界各地. 对于人类行为的起源, 进化心 理学主张: 人类语言、思维和情感是伴随人类进化而 缓慢出现的 ${ }^{[2]}$. 研究者认为, 在非洲的早期智人虽然 在解剖结构上已经接近现代智人, 但其心理和行为 上仍不是现代意义上的智人 ${ }^{[3]}$. 关于人类“革命”(the human revolution)的观点认为，大约 5 万年前或 4 万年 前, 基因突变使人类具有掌握和使用语言的能力. 但 当时在欧亚大陆上生活的尼安德特人(Neanderthals) 的灭绝, 很可能是由于他们没有掌握语言这些特殊 的认知技能 ${ }^{[3]}$. 伴随着人类的进化和繁衍过程, 在适 应自然和学会生存的过程中，人类开始使用工具来 打猎和采集食物; 在这个过程中, 人类使用和掌握语 言、学会合作、进行交易, 并学会使用自然的颜料进 行装饰和艺术创作 ${ }^{[4]}$. 人类生理构造和大脑进化的过 程中导致人类行为的不断进化. 考古学家在南非 Blombos Cave 和Pinnacle Point两处遗址发现距今7 万年 16 万年就有穿孔贝壳、天然颜料和个人的装饰 品. 这个时间与智人出现的时间恰巧重合, 表明现代 人的认知和行为可能是在适应环境过程中逐渐形成 的, 不是任何的突变或文化爆炸(cultural big bang)导 致的 ${ }^{[5 \sim 7]}$. 由此可见, 现代人类的行为不是突然出现 的, 是其适应环境和生存的结果 ${ }^{[8,9]}$. 此观点也得到 了在北非考古结果的支持 ${ }^{[10]}$.

进化心理学是近年来心理学中出现的一股新的 心理学思潮. 达尔文在其《物种起源》末尾曾经展望 “在不久的将来……理学将会依赖于新的依据, 给 
人类历史和人的起源增加新的内容, ${ }^{[8]}$. 进化心理学 的基本观点认为, 人的心理包括成千上万个进化的 模块, 这些模块是心理适应的结果, 它从进化论的角 度出发, 运用进化生物学的资料和方法来探讨人类 心灵的结构和起源 ${ }^{[11]}$. 其中最典型的就是人类对威 胁性刺激物(如蛇或蜘蛛)的快速觉察. 对威胁性动物 恐惧会引发人类一系列的应激反应, 快速逃离威胁 情境, 以使自己生存下来 ${ }^{[12,13]}$. 特定的威胁性刺激对 个体造成的伤害, 使个体牢牢记住该刺激物, 以避免 下次再犯同样的错误, 即所谓的 “一朝被蛇咬, 十年 怕井绳”.

为了更好地适应生存环境, 人类要进化出更高 级的行为 ${ }^{[8]}$. 人类的知觉就是为了适应环境的需要而 进化的, 生存环境中没有需求的知觉能力可能会被 进化所忽视. 在热带雨林中生存的部落, 由于其生活 的环境中物体离眼睛的距离很近, 所以部落个体就 没有像生活在宽广的草原环境下人们一样具备很好 的知觉恒常性 ${ }^{[14]}$. 而知觉的大小恒常、颜色恒常、形 状恒常是生活在广阔环境中的个体必须具有的知觉 能力. 因为知觉的恒常性可以让我们保持对客观事 物的正确知觉.

人类在与环境的相互作用中还习得了特定的思 维模式. 在进人工业社会以前的漫长时期, 男性和女 性扮演着不同的社会角色. 男性专司狩猎, 女性专门 负责采集食物的种子和照顾孩子. 男性和女性进化 出了与此相适应的能力. 由于狩猎通常使男性要走 很远的路程, 因此那些能够找到回家之路的狩猎者 生存了下来, 那些容易迷路的狩猎者则被淘汰. 女性 采集可食用的坚果、块茎和蘑菇, 这需要她们再认和 回忆物体的形状和颜色, 能够辨认其中哪些是见过 的 ${ }^{[9]}$. 心理学研究发现, 在定位记忆任务和物体排列 的空间任务上, 女性比男性更为出色. 同样, 在对不 常见或不能命名的物体的记忆上, 这种性别优势依 然存在. 然而, 在需要心理旋转和陌生地域中识别方 向的空间任务上, 男性比女性表现更好, 研究者假设 人类的记忆应该对与进化有关的内容更加敏感 ${ }^{[15]}$. 研究发现, 与人类生存(如: 事物、捕食者、庇护所) 和繁衍(比如: 交配)密切相关的内容, 被试的回忆效 果要更好 ${ }^{[16]}$.

人类的语言也是伴随进化而产生的, 为人类生 存和现代行为提供了重要的基础 ${ }^{[17]}$. 认知神经科学研 究发现, 人类的前额叶与灵长类、原始人类很相似, 但 是仅仅在人类中发现了元认知执行功能(metacognitive executive functions), 而灵长类和原始人类仅仅具有 情感执行功能(emotional executive functions), 而元认 知执行功能被认为与文化和语言存在密切相关 ${ }^{[18]}$. 人类能够主宰这个星球而大猩猩却濒临灭绝, 其主 要原因不仅仅在于我们人类拥有 $5 \%$ 的特殊DNA, 而 且还在于我们人类能够跨越时空积累文化和传递信 息 ${ }^{[11]}$. 也就是说，一个来到今天的世界的小孩继承 了一套基因, 并从经验中也吸取了很多教训. 但是他 也习得了前人所发明的词语、思想和工具. 人类学家 列夫谢苗诺维奇. 维果茨基在 20 世纪 20 年代就指出, 与其他物种的心智相比, 人的心智更多的是在一个 被称作是文化的海洋里邀游. 他们学习语言, 使用技 术, 共享信念, 习得技巧. 这些都是通过文化将他们 一代代地传递给其他人, 并因此把许多活着的和已 故的个体认知资源汇集在一起 ${ }^{[11,19]}$. 文化心理学 ${ }^{[20]}$ 认为, 人的实践活动或文化与心理的是一个相互作 用的过程, 二者相互建构. 跨文化心理学的研究发 现, 东西方人存在思维方式的差异. 文化神经科学认 为不仅大脑控制认知和文化的交互作用，而且文化 也塑造和调控我们大脑的结构与功能. 如McClure等 人 $^{[21]}$ 通过巧妙的实验设计发现, 携带文化信息的饮 料(可口可乐和百事可乐)能够影响人们味觉的偏好, 而且这种偏好与背外侧前额叶以及海马记忆这两个 神经环路有关.

综上, 本文以进化论的角度出发, 从进化心理学 的视角来探讨现代人行为的起源, 我们认为现代人 的行为是在自然选择的过程中缓慢进化而来的, 人 的每一种行为都是通过传递获得 ${ }^{[19]}$. 这样人类就可 以更好地适应复杂的环境. 进化心理学同意达尔文 “自然选择”观点, 即自然选择是进化的主要机制, 依 据进化心理学 ${ }^{[22]}$, 通过自然选择的进化是复杂的神 经回路和相应的心理机制产生和发展的动力源泉. 任何心理机制的物质基础一一神经回路的建立都是 为了人类更好地适应环境和获得生存. 如果一种神经 回路或者心理机制有利于有机体的生存和繁衍, 那么 它就会被自然“选中”, 获得更大的生存机遇. 换言之, 自然选择用特殊的决策支持了特定的神经回路和心理 机制, 其结果是造成了现代人复杂的神经系统和众多 功能专门化的心理机制. 但是人的行为和人的心理也 是在活动中在刺激的不断作用下形成、发展和深化, 具有文化特征, 文化也会对人的行为有很大影响 ${ }^{[23]}$. 


\section{参考文献}

1 Stringer C. The Origin of Our Species. London: Penguin UK, 2011

2 Oppenheimer S. Out of Eden: The Peopling of the World. Robinson: Constable \& Robinson Ltd, 2004

3 Klein R G. The Human Career: Human Biological and Cultural Origins. 3rd ed. London: University of Chicago Press, 2009

4 McBrearty S, Brooks A S. The revolution that wasn't: A new interpretation of the origin of modern human behavior. J Human Evolut, 2000, 39: 453-563

5 Henshilwood C S, d'Errico F, Yates R, et al. Emergence of modern human behavior: Middle Stone Age engravings from South Africa. Science, 2002, 295: 1278-1280

6 Henshilwood C S, Marean C W. The origin of modern human behavior critique of the models and their test implications. Curr Anthropol, 2003, 44: 627-651

7 Botha R, Knight C. The Cradle of Language. New York: Oxford University Press, 2009

8 Buss D M. The great struggles of life: Darwin and the emergence of evolutionary psychology. Am Psychol, 2009, 64: 140-148

9 Buss D M. Evolutionary Psychology: The New Science of the Mind. Boston: Allyn \& Bacon, 1999

10 Bouzouggar A, Narton N, Vanhaeren M, et al. 82000-year-old shell beads from North Africa and implications for the origins of modern human behavior. Proc Natl Acad Sci USA, 2007, 104: 9964-9969

11 Matte R, ed. Chen H P, Yan C F, trans. Congenital, Acquired, Genes, Experiences, and What Makes Us Who We Are (in Chinese). Beijing: Beijing Institute of Technology Press, 2005. 208-238 [马特·里德利, 著. 陈虎平，严成芬，译. 先天、后天、基因、经验，及什 么使我们成为人? 北京: 北京理工大学出版社, 2005. 208-238]

12 Öhman A, Mineka S. Fears, phobias, and preparedness: Toward an evolved module of fear and fear learning. Psychol Rev, 2001, 108: 483-522

13 Öhman A, Mineka S. The malicious serpent: Snakes as a prototypical stimulus for an evolved module of fear. Curr Direct Psychol Sci, 2003, 12: 5-9

14 Turnbull C. The Forest People. New York: Touchstone, 1987

15 Silverman I, Eals M. The evolutionary psychology of spatial sex differences. In: Crawford C, Krebs D L, eds. Handbook of Evolutionary Psychology. Mahwah: Erlbaum, 1998. 595-612

16 Nairne J S, Pandeirada J N S. Adaptive memory: Remembering with a stone-age brain. Curr Direct Psychol Sci, 2008, 17: 239-243

17 Ferretti F. Was there language outside Homo sapiens? A cognitive perspective. J Anthropol Sci, 2013, 91: 249-251

18 Ardila A. On the evolutionary origins of executive functions. Brain Cogn, 2008, 68: 92-99

19 Thompson B, Kirby S, Smith K. Culture shapes the evolution of cognition. Proc Natl Acad Sci USA, 2016, 113: 4530-4535

20 Li B Q. Comparison and integration of cultural psychology and cross-cultural psychology (in Chinese). Adv Psychol Sci, 2006, 14: 315-320 [李炳全. 文化心理学与跨文化心理学的比较与整合. 心理科学进展, 2006, 14: 315-320]

21 McClure S M, Li J, Tomlin D, et al. Neural correlates of behavioral preference for culturally familiar drinks. Neuron, 2004, 44: 379-387

22 Ye H S. The change of thinking mode of evolutionary psychology and its significance (in Chinese). Adv Psychol Sci, 2005, 13: 847-855 [叶浩生. 进化心理学思维方式的变革及其意义. 心理科学进展, 2005, 13: 847-855]

23 Li B Q, Ye H S. The basic connotation of cultural psychology (in Chinese). Psychol Sci, 2004, 27: 62-65 [李炳全, 叶浩生. 文化心理学 的基本内涵辨析. 心理科学, 2004, 27: 62-65] 


\title{
"What gave rise to modern human behavior?": Perspective from psychology
}

\author{
BAI XueJun \& LI Hui
}

Academy of Psychology and Behavior, Tianjin Normal University, Tianjin 300074, China

In celebration of the 125th anniversary of the first publication of Science magazine in the United States in 2005, the journal made a special list with 125 of the most challenging scientific questions, one of which was, "What gave rise to modern human behaviors? Did Homo sapiens acquire abstract thought, language, and art gradually or in a cultural 'big bang', which in Europe occurred about 40000 years ago?" Data from Africa, where our species arose, might hold the key to the answer. In the last ten years, the advances of research concerning this question from the perspective of psychology had been reviewed. Homo sapiens developed abstract thoughts, languages, and the arts during the evolution of the species. It found that human gene mutation enabled humans to grasp and use languages forty or fifty thousand years ago. As the species developed, humans began to use tools, hunted and gathered food to adapt to their changing place in nature. During this process, humans mastered languages and learned to cooperate, traded with each other, and used natural materials for decoration and artistic expressions. Humans acquired some certain thought models during the interaction with their environment. Human physiological structure and the evolution of the brain shaped their behaviors in their interaction with the environment. Based on these factors, some researchers think that modern human behaviors did not appear suddenly, but rather was the result of adaptation to the environment and the struggle for survival. The basic premise in evolutionary psychology is that people's mental states consist of tens of thousands of modules, which are the results of adaptation to the environment. The process of evolution is accompanied by the development of human languages, which provide an important foundation for human survival and modern behaviors. In order to adapt better to the environment where people live, more advanced behaviors evolved, just as the whales, whose ancestors were land-dwellers, adapted to the environment of the sea. Examples of this are perception ability, the social roles of the genders, gender differences in spatial memory, and cultural psychological differences. Here, an evolutionary perspective is taken to explore the origin of the human minds based on the materials and methods of evolutionary biology, suggesting that modern human behavior is the result of slow evolution and adaptation to the environment. The development of culture has also had a significant impact, and has become one of the defining characteristics of human life.

\section{human behavior, homo sapiens, theory of evolution, psychology, culture}

doi: 10.1360/N972016-00316

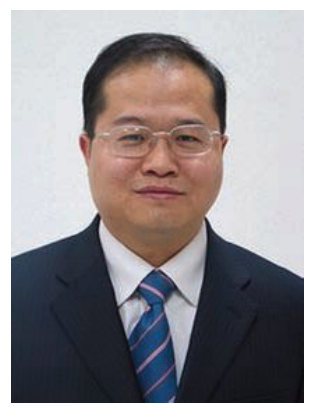

\footnotetext{
白学军

天津师范大学心理与行为研究院院长、教授、博导. 2005 年教育部“新世纪优 秀人才支持计划”人选; 2006 年“新世纪百千万人才工程”国家级人选. 2011 年 享受国务院政府特殊津贴. 2014 年天津市教学名师. 2014 年中宣部文化名家 暨“四个一批”人才, 2015 年“万人计划”哲学社会科学领军人才. 任中国心理 学会候任理事长、国务院学位委员会心理学科评审组成员、教育部教学指导 委员会心理学类专业副主任, 《心理与行为研究》主编. 主要研究领域: 阅 读能力、高效率学习、智力发展与培养、青少年心理健康.
} 